\title{
Psychological co-morbidities and functional neurological disorders in idiopathic urinary retention: International Consultation on Incontinence Research Society (ICI-RS) 2019
}

\begin{tabular}{|r|l|}
\hline Journal: & Neurourology and Urodynamics \\
\hline Manuscript ID & Draft \\
\hline Wiley - Manuscript type: & Sounding Board \\
\hline Subject Sections: & LUTS (female), Neurourology: Clinical \\
\hline Keywords: & $\begin{array}{l}\text { Psychological disorders, anxiety, functional neurological symptom } \\
\text { disorders, FND, urinary retention, Fowler's syndrome }\end{array}$ \\
\hline
\end{tabular}

\section{SCHOLARONE Manuscripts}




\begin{abstract}
Aims:

Chronic urinary retention occurring in young women is poorly understood and a cause may not be found in a majority of cases. Different psychological co-morbidities and functional neurological symptom disorders (FNDs) have been reported, however these have been poorly explored.
\end{abstract}

Methods: At the International Consultation on Incontinence Research Society (ICl-RS) meeting in 2019, a panel of clinicians generated a proposal to explore the relationship between psychological co-morbidities, FNDs and urinary retention in women with chronic idiopathic urinary retention.

Results: Psychological co-morbidities such as depression and anxiety, and FNDs such as leg weakness and loss of consciousness, have been reported in women with idiopathic urinary retention. Individuals react differently to physical and emotional stressors, and experimental models have demonstrated a relationship between the stress response and developing urinary retention. Trauma, particularly sexual trauma, may be a shared risk factor for developing psychological co-morbidities and urinary retention. Children with voiding postponement often suffer from psychological co-morbidities and behavioral disturbances, however there is 
no evidence to suggest that this progresses to urinary retention in adulthood. "Psychogenic urinary retention" has been described in the urology and psychiatry literature in the past, and anecdotal cases of successful voiding following psychotherapy have been reported, though the true pathophysiology of this entity is uncertain.

Conclusion: Psychological and functional disorder co-morbidities are reported in women with chronic urinary retention. The nature of the association between urinary retention and functional neurological disorder co-morbidities needs to be further explored in terms of a disorder of bladder-brain interaction. 


\title{
Introduction
}

Chronic urinary retention occurring in young women is poorly understood. The urological assessment is useful in clinical phenotyping, to establish whether urinary retention is due to detrusor underactivity and/or bladder outlet obstruction (BOO) (1). There are several causes for chronic urinary retention, however an aetiology may not be found despite an extensive urological and neurological assessment (2) (3). In women with chronic idiopathic urinary retention, outcomes following treatment with sacral neuromodulation are mixed, however women with evidence of a functional BOO, specially with evidence for a primary disorder of external urethral sphincter relaxation by urethral pressure profilometry and/or urethral sphincter EMG (sometimes referred to as Fowler's syndrome), have shown a more favourable response to treatment (4) (5).

\begin{abstract}
A number of studies have suggested the co-occurrence of different psychological and functional disorders in women with chronic idiopathic urinary retention (6) (7) (4) (8) (9) (10). From the available evidence, the commonest are affective disorders such as depression and anxiety, and functional disorders such as fibromyalgia, irritable bowel syndrome and functional neurological symptom disorders (FNDs) such as limb weakness
\end{abstract}


and non-epileptic attacks (9) (10). Historically, urological and psychological management have not been joined-up, and therefore the coexistence of urinary retention and psychological/ functional disorder comorbidities has been poorly acknowledged and researched. The aim of this paper is to highlight gaps in the understanding of these co-morbidities, and to explore the nature of their relationship with urinary retention.

\section{Methods}

At the International Consultation on Incontinence Research Society (IClRS) held in Bristol, United Kingdom in 2019, a panel of clinicians participated in a discussion on psychological co-morbidities and FNDs reported in women with chronic idiopathic urinary retention. The panellists reviewed the different co-morbidities reported in the literature, how these were assessed, risk factors for developing these co-morbidities and outcomes following treatments. The panel also explored possible causal associations between these co-morbidities and developing urinary retention. From the discussions at the meeting and subsequent e-mail iterations, the panel proposed priority areas for further research.

\section{Psychological co-morbidities}


The two main classification systems of mental and behavioural disorders are the International Classification of Diseases ICD-11 (11) published by the World Health Organisation which has a chapter on mental and behavioural disorders, and the Diagnostic and Statistical Manual (DSM-5) (12) published by the American Psychiatric Association. Whilst the DSM is the most widely-used diagnostic system in the United States, the ICD is used more widely in Europe and other regions of the world. Mental, psychological and behavioural disorders reported in women with idiopathic urinary retention are collectively known as "psychological co-morbidities" in this paper.

In recent years, a number of screening questionnaires have become available to screen for different psychological co-morbidities. Many of these are self-reported and therefore can be completed by the patient. When assessing psychological co-morbidities in the medical setting, it is common to screen mainly for affective disorders (mood disorders), particularly depression and anxiety. Screening tools will usually have cut-off scores, suggesting a threshold score for 'caseness' and also an indication of severity of anxiety or depression. However, other psychological comorbidities should be screened as well. In the United Kingdom, the Improving Access to Psychological Therapies (IAPT) programme has 
transformed treatment of psychological disorders and provides evidence based treatments for people with anxiety and depression, implementing National Institute of Clinical Excellence (NICE) guidelines. The brief screening tools approved by IAPT for case identification are listed in Table 1 (13) (14) (15) (16) (17) (18) (19) (20) (21) (22) (23) (24). A broadband questionnaire recommended for children is the Child Behavior Checklist (25). A formal assessment of mental health difficulties includes a semistructured clinical interview carried out by a qualified mental health professional, accompanied by mental health and physical examination and psychological testing. Structured interview schedules have been developed with the goal of improving diagnostic reliability.

\section{Functional neurological symptom disorders}

FNDs are characterised by the presence of altered voluntary motor or sensory function which are incompatible with recognized neurological or medical conditions. These include limb weakness, sensory disturbances, nonepileptic attacks and memory impairment, which cannot be explained by a neurological or other medical condition, and can cause a significant degree of distress warranting medical evaluation. FNDs can overlap with 
other functional disorders such as fibromyalgia, chronic fatigue syndrome and irritable bowel syndrome. The term "conversion disorder" is retained under DSM-5, however psychological stressors may not be readily identifiable in all cases (26). Individuals with FNDs do not falsify physical or psychological signs, and therefore this condition is different from factitious disorders or malingering. Functional neurological symptom disorders have a reported incidence of 4 to 12 per 100000 population per year and a prevalence of 50 per 100000 population based on a community registry (27) (28) (29), and more prevalent in females(27).

A diagnosis of FND is made based upon the history and physical examination identifying specific neurological signs (26). A screening questionnaire for FNDs has been designed, however has limited sensitivity and specificity except for diagnosing "blackouts" (30).

\section{Prevalence of co-morbidities in women with urinary retention}

A number of functional and affective symptoms are known to co-exist with LUT disorders such as OAB and Bladder Pain Syndrome (31) (32) (33), as well as other visceral disorders such as irritable bowel syndrome (34). The burden of psychological co-morbidities and functional disorders amongst 
women with idiopathic urinary retention is difficult to estimate, however from the evidence available prevalence of affective symptoms appears to be greater amongst $\mathrm{OAB}$ patients compared to urinary retention (9). The few studies that have evaluated psychological co-morbidities in women with idiopathic urinary retention have focused only on affective disorders, and the use of different screening questionnaires precludes comparison between studies (Table 2). These studies suggest the occurrence of different co-morbidities, namely depression requiring hospitalisation, "hysteria", depression, risk of somatisation, definitive somatoform disorder and unspecified psychiatric disorders (6) (7) (4) (8). The prevalence of other behavioural disorders such as phobias and PTSD, which are likely to have a relationship with lower urinary tract (LUT) functions, is unknown.

FNDs are under-recognised, partly due to the absence of a sufficiently robust screening tool, however from the evidence available the prevalence appears to be greater than in the general population (Table 2) (30) (10). In a cohort of 62 women with Fowler's syndrome, $24 \%$ had medically unexplained/"functional" symptoms which included loss of consciousness, limb weakness, sensory disturbance and memory impairment. Furthermore, almost a third (31\%) had psychological co-morbidities such 
as anxiety/depression or obsessive compulsive symptoms (10). Nearly $50 \%$ of women suffered from unexplained chronic abdomino-pelvic, back, leg or widespread pain (10) and use of opiate medications, which may interfere with LUT functions and cause urinary retention, was found to be common (2).

\section{Vulnerability to developing psychological co-morbidities}

In pelvic disorders with a substantial functional component, such as bladder pain syndrome, chronic pelvic pain syndrome and overactive bladder $(O A B)$, it is hypothesised that an imbalance between resilience and vulnerability could lead to a sensitized defence reaction and alarm falsification in reaction to multiple cumulative threats. These threats could either be physical, such as an infection, or emotional, such as childhood adversity or emotional or sexual abuse (35). The balance between vulnerability and resilience is explained by a 3-hit concept of genetic predisposition, early-life environment and later-life environment (36). Therefore, stress in early life can influence brain plasticity with lasting effects, and epigenetic factors in combination with genetic predisposition can influence vulnerability or resilience to stress (37). For example, personality traits might predispose to vulnerability to functional urological 
symptoms. "Neuroticism", a personality trait associated with a bias towards negative emotions, is associated with $O A B$ (38). The importance of vulnerability was underscored by a large population-based study where urinary incontinence was significantly associated with psychological problems with feelings of vulnerability (39). To conclude, there is a difference to how people react to different kinds of physical and emotional stressors.

\section{Relationship between stress and urinary retention- biological models}

Chronic stress response can lead to changes in visceral organs. Studies in mice have shown that mild social stress led to OAB behaviour(40) while prolonged exposure to stress resulted in an increase in intermicturition interval and voided volume, which are indicative of bladder underactivity. These functional changes were accompanied by increased collagen deposition and bladder wall remodeling (41). Bladder dysfunction therfore progresses from overactivity to underactivity as the intensity and duration of social stress increases, at least in experimental animal models (42). Functional changes of voiding dysfunction may persist even after removal of the stressor (43). 
In male rats exposed to social stress, corticotropin releasing factor (CRF) receptor expression was upregulated in the Barrington's nucleus (44). In the hypothalamic-pituitary-adrenal (HPA) axis, CRF, a neuropeptide secreted by the paraventricular nucleus of the hypothalamus, is involved in the stress response by stimulating the pituitary release of ACTH which has inhibitory effects on the micturition pathway (45). In humans, urinary retention has been reported to occur following social stressors such as the loss of a loved one or a recent divorce (46), and social stress-induced voiding dysfunction seen in animal models could provide a biological explantion for this observation.

\section{Sexual Trauma- shared risk factor for developing psychological co- morbidities and chronic urinary retention?}

Victims of rape or sexual abuse are prone to develop post-traumatic stress disorder (PTSD) and other psychological disorders as anxiety, depression and psychosis (47) (48) (49). The symptoms can occur immediately or with delayed onset. Additionally, occurrence of these disorders is more likely to be associated with a reduction in quality of life, increase in morbid obesity, marital instability, high use of medical care and somatic symptoms such as gastrointestinal symptoms and recurrent headache (50). 
Moreover, patients who were sexually abused in childhood may also present with genitourinary symptoms. Zhao et al. recently reported an association between bullying and childhood LUT symptoms. This is also true for adults who have experienced sexual abuse, where storage symptoms such as nocturia, urinary frequency and urgency have been reported (51). However the prevalence of voiding difficulties amongst victims of sexual abuse has been poorly explored and Williams et al. (52) has reported a case of episodic urinary retention in a woman who experienced recurrent sexual trauma. Other pelvic symptoms reported by individuals who have experienced abuse include pelvic pain (53), dyspareunia and symptoms of prolapse (54) (55).

\section{Voiding postponement in childhood -a precursor to developing urinary retention in adults?}

Voiding postponement (VP) is defined as a habitual postponement of micturition by using holding maneuvers (56). Typical symptoms are low micturition frequency, feeling of urgency and possibly incontinence from a full bladder. Concomitantly, children with VP often suffer from psychological co-morbidities or behavioral disturbances such as Oppositional Defiant 
Disorder (ODD). The prevalence of ODD is $2-5 \%$ and typical symptoms are a persistent angry and irritable mood, argumentative, defiant behavior and vindictiveness.

Voiding postponement can develop as a learned behavior, leading to shortterm positive effects of not needing to void in a specific social situation, however can persist despite negative consequences such as incontinence. This habit is often maintained for convenience, because of the fear of missing out (e.g. in play), due to unhygienic toilets in school, as a component of ODD. Some children develop VP without precursors, however the sequence from OAB, to VP, due to increased activation of pelvic floor muscles, to dysfunctional voiding and finally to underactive bladder is possible. Typical signs of VP are abnormal uroflow curves (plateau, staccato, intermittent), non-relaxed pelvic floor EMG activity, increased postvoid residual urine, increased maximal voided volumes, constipation, UTI's, dysfunctional family dynamics, lower quality of life and externalization of behavioural disorders. The mainstay of treatment of VP is timed voiding (7 times/day) with a continuous documentation using charts and positive reinforcement. Timer watches (or mobile phones) can 
be useful adjuncts to serve as reminders to void regularly. In refractory cases, outpatient training programs have been shown to be efficient.

Voiding postponement affects $13.7 \%$ of adolescents (57) and occurs more likely if bladder control had been delayed or if daytime urinary incontinence, has been present in childhood. No studies have assessed the natural history of VP in boys and girls through adolescence to adulthood.

\section{Discussion}

\section{“Psychogenic urinary retention"- terminology from a bygone era?}

The Urology literature

Neuro-urology textbooks of more than 3 decades ago defined the umbrella term "psychogenic urinary dysfunction" (PUD) to cover not only urinary retention, but also any difficulty in voiding, paruresis and even overactive bladder $(\mathrm{OAB})$ based on a diagnosis of exclusion of all urologic, gynecologic, and neurologic causes (58) (59). Manifest psychological features accompanying the LUT dysfunction were required to meet the definition of PUD (59) and PUD was considered to be a psychosomatic disorder affecting the lower urinary tract function (59). Nowadays, using the term PUD is unhelpful as it represents a heterogeneous group of patients with functional bladder disorders covering the spectrum from $O A B$ 
to bladder emptying problems. Moreover, investigations have become better refined to recognize a biological basis for disease. For example, urethral sphincter electromyography may demonstrate a characteristic abnormal pattern of activity in some women with urinary retention, and functional MRI studies suggest that brain responses to bladder filling are abnormal, which correlated with maximum urethral closure pressure (60).

However, few studies have evaluated the changes in psychological comorbidities following urological interventions for urinary retention. Only affective symptoms have been studied and in a cohort of patients undergoing SNM, significant improvements in voiding symptoms and quality of life for idiopathic urinary retention were not accompanied with improvements in depression/anxiety symptoms, in contrast to patient with OAB where improvements were seen in patients with successful outcomes (9). In an Italian registry study, most of the treatment failures belonged to a group with psychological disorders such as "hysteria", depression and hypochondria, suggesting a worse outcome in this group (7).

The Psychiatry literature 
In the past, a psychological cause for urinary retention was considered acceptable, and Table 3 traces this history through earlier versions of the DSM (61) (62). This older literature documented a variety of predisposing and precipitating factors including major stressful life-events (63). A full review of the history of how psychological factors were understood to play a role in the aetiology of urinary retention is complicated by changes in diagnostic criteria and labelling, e.g. 'psychogenic urinary retention', 'hysteria', 'somatisation', conversion disorder, medically unexplained symptoms.

Reports of "successful treatment" of urinary retention by psychotherapy can in fact be found in the historical literature on 'Psychogenic urinary retention' (Table 4) (52) (64) (65) $(66)(67,68)(69)(70)(71)(72)$. In most cases, a history of conflict or trauma was reported and authors claimed that psychotherapy was found to be effective in relieving urinary retention, as well as improving other areas e.g. family and/or marital relationships.

Modern day classifications in urology and psychiatry practice however fail to mention "psychogenic urinary retention" and the reasons for this are unclear. The true pathophysiology of this entity is uncertain, however the 
availability of advanced urological and neurological diagnostic tests in the modern day (1) have helped to uncover a biological cause for urinary retention in a substantial number of patients who, in the past, would have been labelled to have "idiopathic urinary retention" (1).

Could the co-occurrence of FNDs and idiopathic urinary retention suggest a disorder of "bladder-brain interaction"?

Despite advances in diagnostic testing, the cause for urinary retention is found in only $40 \%$ of women (2). The search for putative organic mechanisms continues, however the high prevalence of functional disorders in women with idiopathic urinary retention compared to the general population is unlikely to be co-incidental. It is tempting to speculate that in some patients urinary retention may reflect a disorder of "bladderbrain interaction". For example, patients with functional motor weakness experience an unintentional loss of somatic function manifesting as limb weakness. Could some cases of chronic idiopathic urinary retention represent a functional disorder characterized by a loss of visceral organ (LUT) functions and a central failure to initiate detrusor contractions (73)? It is noteworthy that amongst patients with functional movement disorders, particularly functional dystonias, urinary retention is the commonest LUT 
dysfunction reported (74). LUT functions are controlled centrally by an elaborate neuronal network distributed across different cortical regions, and bladder storage and emptying are learned behaviours (75). The ventromedial prefrontal cortex (PFC) is a key limbic structure that plays an important role in LUT control (76), as is involved in decision making in an emotional and social context (77). The same region is also implicated as a relay centre between emotional regulation and complex body function control. Functional brain imaging studies have demonstrated abnormalities in this region in patients with functional disorders, suggesting that these patients might have an abnormal affective representation of self-relevant information encoded in this region (78) (79). Whether alterations in medial PFC activity represent a common biological abnormality for FNDs and urinary retention requires to be further explored.

It is possible that in some cases, urinary retention may be a manifestation of a functional disorder. However there are a number of gaps in our understanding of chronic idiopathic urinary retention in women, and with the availability of advanced urological and neurological diagnostic tools for investigating the cause for urinary retention, as well as an enhanced understanding of behavioural disorders and FNDs, further research is 
needed to explore possible causal associations. Multi-centric crosssectional and longitudinal studies of women with idiopathic urinary retention undergoing a comprehensive assessment of psychological and functional co-morbidities are needed to answer the following inter-related research questions:

1. In some cases, can urinary retention be a manifestation of a functional disorder?

2. What is the prevalence of different psychological co-morbidities and functional disorders in women with idiopathic urinary retention? Does this differ from other idiopathic LUT disorders such as OAB?

3. Amongst women with idiopathic urinary retention, are there differences in patient characteristics between those with FNDs and those without?

4. What is the relationship between chronic stress response and developing urinary retention in humans? Can physical or sexual abuse trigger a stress response culminating in urinary retention? 
5. Is voiding postponement in the context of oppositional defiance disorder in childhood a risk factor for developing urinary retention in later life?

6. In women with idiopathic urinary retention undergoing sacral neuromodulation-

- Do the outcomes differ in women who have psychological comorbidities and functional disorders?

- Do psychological co-morbidities and functional disorders improve in women with successful urological outcomes?

7. In women with idiopathic urinary retention who are undergoing behavioural therapies for co-existant psychological co-morbidities or functional disorders, do any of these therapies ameliorate voiding dysfunction?

Conclusion: From the available evidence, psychological and functional disorder co-morbidities often co-occur in women with chronic idiopathic urinary retention. The nature of the association between urinary retention and functional neurological disorder co-morbidities needs to be further explored in terms of a disorder of bladder-brain interaction. 


\section{Acknowledgments}

JNP undertook this work at UCLH/UCL Institute of Neurology and is supported in part by funding from the United Kingdom's Department of Health NIHR Biomedical Research Centres funding scheme. CS and JNP acknowledge support from the Small Acorns Grant of The National Brain Appeal. JNP acknowledges Professor Jon Stone, Centre for Clinical Brain Sciences, University of Edinburgh, for his critical review of the manuscript. 


\section{References}

1. Panicker JN, Anding R, Arlandis S, Blok B, Dorrepaal C, Harding C, Marcelissen T, Rademakers K, Abrams P, Apostolidis A. Do we understand voiding dysfunction in women? Current understanding and future perspectives: ICI-RS 2017". Neurourol Urodyn 2018;37:S75-S85.

2. Panicker JN, Game X, Khan S, Kessler TM, Gonzales G, Elneil S, Fowler CJ. The possible role of opiates in women with chronic urinary retention: observations from a prospective clinical study". J Urol 2012;188:480-484.

3. Groutz A, Blaivas JG. Non-neurogenic female voiding dysfunction". Curr Opin Urol 2002;12:311-316.

4. De Ridder D, Ost D, Bruyninckx F. The presence of Fowler's syndrome predicts successful long-term outcome of sacral nerve stimulation in women with urinary retention". Eur Urol 2007;51:229-233; discussion 233-224. 
5. Datta SN, Chaliha C, Singh A, Gonzales G, Mishra VC, Kavia RB, Kitchen N, Fowler CJ, Elneil S. Sacral neurostimulation for urinary retention: 10-year experience from one UK centre". BJU Int 2008;101:192-196.

6. Everaert K, De Ridder D, Baert L, Oosterlinck W, Wyndaele JJ. Patient satisfaction and complications following sacral nerve stimulation for urinary retention, urge incontinence and perineal pain: a multicenter evaluation". Int Urogynecol J Pelvic Floor Dysfunct 2000;11:231-235; discussion 236.

7. Marcelissen TA, Leong RK, Nieman FH, van Lankveld JJ, van Kerrebroeck PE, de Wachter SG. Psychological and psychiatric factors as predictors for success in sacral neuromodulation treatment". BJU Int 2011;108:1834-1838.

8. Spinelli M, Bertapelle P, Cappellano F, Zanollo A, Carone R, Catanzaro F, Giardiello G, De Seta F, Gins G. Chronic sacral neuromodulation in patients with lower urinary tract symptoms: results from a national register". J Urol 2001;166:541-545. 
9. Drossaerts J, Vrijens D, Leue C, Schilders I, Van Kerrebroeck P, van Koeveringe G. Screening for depression and anxiety in patients with storage or voiding dysfunction: A retrospective cohort study predicting outcome of sacral neuromodulation". Neurourol Urodyn 2016;35:1011-1016.

\begin{abstract}
10. Hoeritzauer I, Stone J, Fowler C, Elneil-Coker S, Carson A, Panicker J. Fowler's syndrome of urinary retention: A retrospective study of co-morbidity". Neurourol Urodyn 2016;35:601-603.
\end{abstract}

\begin{abstract}
11. World Health Organization. International classification of diseases for mortality and morbidity statistics (11th Revision). Retrieved from https://icd.who.int/browse11/l-m/en". 2018.
\end{abstract}

12. American Psychiatric Association. Diagnostic and statistical manual of mental disorders (5th ed.)". 2013.

13. The National Collaborating Centre for Mental Health. The Improving Access to Psychological Therapies Manual2018. 
14. Kroenke K, Spitzer RL, Williams JB. The PHQ-9: validity of a brief depression severity measure". J Gen Intern Med 2001;16:606-613.

15. Spitzer RL, Kroenke K, Williams JB, Lowe B. A brief measure for assessing generalized anxiety disorder: the GAD-7". Arch Intern Med 2006;166:1092-1097.

16. Connor KM, Davidson JR, Churchill LE, Sherwood A, Foa E, Weisler RH. Psychometric properties of the Social Phobia Inventory (SPIN). New self-rating scale". $\mathrm{Br} J$ Psychiatry 2000;176:379-386.

17. Chambless DL, Caputo GC, Jasin SE, Gracely EJ, Williams C. The Mobility Inventory for Agoraphobia". Behav Res Ther 1985;23:35-44.

18. Foa E, Kozak M, Salkovskis $P$, Coles M, Amir N. The validation of a new obsessive-compulsive disorder scale: the Obsessive- 
Compulsive Inventory". Psychological Assessment 1998;10:206214.

19. Shear MK, Brown TA, Barlow DH, Money R, Sholomskas DE, Woods SW, Gorman JM, Papp LA. Multicenter collaborative panic disorder severity scale". Am J Psychiatry 1997;154:1571-1575.

20. Kroenke K, Spitzer RL, Williams JB. The PHQ-15: validity of a new measure for evaluating the severity of somatic symptoms". Psychosom Med 2002;64:258-266.

21. Francis CY, Morris J, Whorwell PJ. The irritable bowel severity scoring system: a simple method of monitoring irritable bowel syndrome and its progress". Aliment Pharmacol Ther 1997;11:395402.

22. Cella M, Chalder T. Measuring fatigue in clinical and community settings". J Psychosom Res 2010;69:17-22. 
23. Mundt JC, Marks IM, Shear MK, Greist JH. The Work and Social Adjustment Scale: a simple measure of impairment in functioning". Br J Psychiatry 2002;180:461-464.

24. Weiss D. The Impact of Events Scale-Revised. In: Wilson J, Keance T editors. Assessing Psychological Trauma and PTSD: A practitioner's handbook. New York: Guilford Press; 2007. pp. 168189.

25. Chase J, Bower W, Gibb S, Schaeffer A, von Gontard A. Diagnostic scores, questionnaires, quality of life, and outcome measures in pediatric continence: A review of available tools from the International Children's Continence Society". J Pediatr Urol 2018;14:98-107.

26. Espay AJ, Aybek S, Carson A, Edwards MJ, Goldstein LH, Hallett M, LaFaver K, LaFrance WC, Jr., Lang AE, Nicholson T, Nielsen G, Reuber M, Voon V, Stone J, Morgante F. Current Concepts in Diagnosis and Treatment of Functional Neurological Disorders". JAMA Neurol 2018;75:1132-1141. 
27. Carson A, Lehn A. Epidemiology". Handb Clin Neurol 2016;139:47-60.

28. Szaflarski JP, Ficker DM, Cahill WT, Privitera MD. Four-year incidence of psychogenic nonepileptic seizures in adults in hamilton county, OH". Neurology 2000;55:1561-1563.

29. Binzer M, Andersen PM, Kullgren G. Clinical characteristics of patients with motor disability due to conversion disorder: a prospective control group study". J Neurol Neurosurg Psychiatry 1997;63:83-88.

30. Shipston-Sharman O, Hoeritzauer I, Edwards M, Reuber M, Carson A, Stone J. Screening for functional neurological disorders by questionnaire". J Psychosom Res 2019;119:65-73.

31. Buffington CA. Comorbidity of interstitial cystitis with other unexplained clinical conditions". J Urol 2004;172:1242-1248. 
32. Warren JW, van de Merwe JP, Nickel JC. Interstitial cystitis/bladder pain syndrome and nonbladder syndromes: facts and hypotheses". Urology 2011;78:727-732.

33. Vrijens D, Drossaerts J, van Koeveringe G, Van Kerrebroeck $P$, van Os $J$, Leue $C$. Affective symptoms and the overactive bladder - a systematic review". J Psychosom Res 2015;78:95-108.

34. Riedl A, Schmidtmann M, Stengel A, Goebel M, Wisser AS, Klapp BF, Monnikes H. Somatic comorbidities of irritable bowel syndrome: a systematic analysis". J Psychosom Res 2008;64:573582.

35. Leue C, Kruimel J, Vrijens D, Masclee A, van Os J, van Koeveringe G. Functional urological disorders: a sensitized defence response in the bladder-gut-brain axis". Nat Rev Urol $2017 ; 14: 153-163$.

36. Daskalakis NP, Bagot RC, Parker KJ, Vinkers $\mathrm{CH}$, de Kloet ER. The three-hit concept of vulnerability and resilience: toward 
understanding adaptation to early-life adversity outcome". Psychoneuroendocrinology 2013;38:1858-1873.

37. Papadopoulou Z, Vlaikou AM, Theodoridou D, Markopoulos GS, Tsoni K, Agakidou E, Drosou-Agakidou V, Turck CW, Filiou MD, Syrrou M. Stressful Newborn Memories: Pre-Conceptual, In Utero, and Postnatal Events". Front Psychiatry 2019;10:220.

38. Hsiao SM, Liao SC, Chen $\mathrm{CH}$, Chang TC, Lin $\mathrm{HH}$. Psychometric assessment of female overactive bladder syndrome and antimuscarinics-related effects". Maturitas 2014;79:428-434.

39. Franzen K, Johansson JE, Andersson G, Pettersson N, Nilsson K. Urinary incontinence in women is not exclusively a medical problem: a population-based study on urinary incontinence and general living conditions". Scand J Urol Nephrol 2009;43:226-232.

40. Mingin GC, Heppner TJ, Tykocki NR, Erickson CS, Vizzard MA, Nelson MT. Social stress in mice induces urinary bladder 
overactivity and increases TRPV1 channel-dependent afferent nerve activity". Am J Physiol Regul Integr Comp Physiol 2015;309:R629-638.

41. Mingin GC, Peterson A, Erickson CS, Nelson MT, Vizzard MA. Social stress induces changes in urinary bladder function, bladder NGF content, and generalized bladder inflammation in mice". Am J Physiol Regul Integr Comp Physiol 2014;307:R893-900.

42. Tykocki NR, Heppner TJ, Erickson CS, van Batavia J, Vizzard MA, Nelson MT, Mingin GC. Development of stress-induced bladder insufficiency requires functional TRPV1 channels". Am J Physiol Renal Physiol 2018;315:F1583-F1591.

43. Butler S, Luz S, McFadden K, Fesi J, Long C, Spruce L, Seeholzer S, Canning D, Valentino R, Zderic S. Murine social stress results in long lasting voiding dysfunction". Physiol Behav 2018;183:10-17. 
44. Wood SK, Baez MA, Bhatnagar S, Valentino RJ. Social stressinduced bladder dysfunction: potential role of corticotropinreleasing factor". Am J Physiol Regul Integr Comp Physiol 2009;296:R1671-1678.

45. Pavcovich LA, Valentino RJ. Central regulation of micturition in the rat the corticotropin-releasing hormone from Barrington's nucleus". Neurosci Lett 1995;196:185-188.

46. Fenster $\mathrm{H}$, Patterson $\mathrm{B}$. Urinary retention in sexually abused women". Can J Urol 1995;2:185-188.

47. Barbe RP, Bridge JA, Birmaher B, Kolko DJ, Brent DA. Lifetime history of sexual abuse, clinical presentation, and outcome in a clinical trial for adolescent depression". J Clin Psychiatry 2004;65:77-83.

48. Felitti VJ. Long-term medical consequences of incest, rape, and molestation". South Med J 1991;84:328-331. 
49. Read J, Ross CA. Psychological trauma and psychosis: another reason why people diagnosed schizophrenic must be offered psychological therapies". J Am Acad Psychoanal Dyn Psychiatry 2003;31:247-268.

50. Dickinson LM, deGruy FV, 3rd, Dickinson WP, Candib LM. Health-related quality of life and symptom profiles of female survivors of sexual abuse". Arch Fam Med 1999;8:35-43.

51. Link CL, Lutfey KE, Steers WD, McKinlay JB. Is abuse causally related to urologic symptoms? Results from the Boston Area Community Health (BACH) Survey". Eur Urol 2007;52:397-406.

52. Williams GE, Johnson AM. Recurrent urinary retention due to emotional factors; report of a case". Psychosom Med 1956;18:7780.

53. Davila GW, Bernier F, Franco J, Kopka SL. Bladder dysfunction in sexual abuse survivors". J Urol 2003;170:476-479. 
54. Nault T, Gupta P, Ehlert M, Dove-Medows E, Seltzer M, Carrico DJ, Gilleran J, Bartley J, Peters KM, Sirls L. Does a history of bullying and abuse predict lower urinary tract symptoms, chronic pain, and sexual dysfunction?". Int Urol Nephrol 2016;48:17831788.

55. Seltzer MB, Long RA. Bullying in an adolescent and young adult gynecology population". Clin Pediatr (Phila) 2013;52:156161.

56. Austin PF, Bauer SB, Bower W, Chase J, Franco I, Hoebeke P, Rittig S, Walle JV, von Gontard A, Wright A, Yang SS, Neveus $\mathrm{T}$. The standardization of terminology of lower urinary tract function in children and adolescents: Update report from the standardization committee of the International Children's Continence Society". Neurourol Urodyn 2016;35:471-481.

57. Heron J, Grzeda MT, von Gontard A, Wright A, Joinson C. Trajectories of urinary incontinence in childhood and bladder and bowel symptoms in adolescence: prospective cohort study". BMJ Open 2017;7:e014238. 
58. Abel G, Blendinger D. Behavioral urology. In: Yalla S, McGuire E, Elbadawi A, Blaivas $\mathrm{J}$ editors. Neurourology and urodynamics Principles and practice. New York:: Macmillan Publishing Company; 1988. pp. 399-409.

59. Siroky M, Krane R. Psychogenic voiding dysfunction. In: Yalla S, McGuire E, Elbadawi A, Blaivas J editors. Neurourology and urodynamics Principles and practice. New York: Macmillan Publishing Company; 1988. pp. 358-370.

60. Kavia R, Dasgupta R, Critchley H, Fowler C, Griffiths D. A functional magnetic resonance imaging study of the effect of sacral neuromodulation on brain responses in women with Fowler's syndrome". BJU Int 2010;105:366-372.

61. American Psychiatric Association. Diagnostic and statistical manual of mental disorders (3rd ed. revised)". 1987. 
62. American Psychiatric Association. Diagnostic and statistical manual of mental disorders (4th ed. text review)". 2000.

63. Hoeritzauer I, Phe V, Panicker JN. Urologic symptoms and functional neurologic disorders". Handb Clin Neurol 2016;139:469481.

64. Chapman AH. Psychogenic urinary retention in women; report of a case". Psychosom Med 1959;21:119-122.

65. Larson J, Swendon W, Utz D, Steinhilber R. Psychogenic urinary retention in women". JAMA internal medicine 1963;184:697-700.

66. Wahl CW, Golden JS. Psychogenic Urinary Retention; Report of 6 Cases". Psychosom Med 1963;25:543-555.

67. Cooper AJ. Conditioning Therapy in Hysterical Retention of Urine". Br J Psychiatry 1965;111:575-577. 
68. Barnard GW, Flesher CK, Steinbook RM. The treatment of urinary retention by aversive stimulus cessation and assertive training". Behav Res Ther 1966;4:232-236.

69. Barrett DM. Evaluation of psychogenic urinary retention". J Urol 1978;120:191-192.

70. Montague DK, Jones LR. Psychogenic urinary retention". Urology 1979;13:30-35.

71. Bird JR. Psychogenic urinary retention". Psychother Psychosom 1980;34:45-51.

72. Wheeler JS, Jr., Culkin DJ, Walter JS, Flanigan RC. Female urinary retention". Urology 1990;35:428-432.

73. Tarcan T, Rademakers K, Arlandis S, von Gontard A, van Koeveringe GA, Abrams P. Do the definitions of the underactive bladder and detrusor underactivity help in managing patients: 
International Consultation on Incontinence Research Society (IClRS) Think Tank 2017?". Neurourol Urodyn 2018;37:S60-S68.

74. Batla A, Parees I, Edwards MJ, Stamelou M, Bhatia KP, Panicker JN. Lower urinary tract dysfunction in patients with functional movement disorders". J Neurol Sci 2016;361:192-194.

75. Fowler CJ, Griffiths D, de Groat WC. The neural control of micturition". Nat Rev Neurosci 2008;9:453-466.

76. Griffiths D. Functional imaging of structures involved in neural control of the lower urinary tract". Handb Clin Neurol 2015;130:121-133.

77. Damasio AR. The somatic marker hypothesis and the possible functions of the prefrontal cortex". Philos Trans R Soc Lond B Biol Sci 1996;351:1413-1420.

78. Aybek S, Vuilleumier P. Imaging studies of functional neurologic disorders". Handb Clin Neurol 2016;139:73-84. 
79. Vuilleumier P. Brain circuits implicated in psychogenic paralysis in conversion disorders and hypnosis". Neurophysiol Clin 2014;44:323-337. 
Table 1. Commonly-used screening tools for psychological / psychiatric morbidity in adults (adapted from The Improving Access to Psychological therapies (IAPT) Manual (13)).

\begin{tabular}{|c|c|c|}
\hline $\begin{array}{l}\text { Measures } \\
\text { questionnaire }\end{array}$ & Domains covered & Items \\
\hline PHQ-9 (14) & Depression & 9 items \\
\hline GAD-7 (15) & Anxiety & 7 items \\
\hline $\begin{array}{l}\text { Social } \\
\text { Inventory } \\
\text { (SPIN) (16) }\end{array}$ & Social phobia & 17 items \\
\hline $\begin{array}{l}\text { Impact of Events } \\
\text { Scale-Revised (IES-R) } \\
(24)\end{array}$ & PTSD & 22 items \\
\hline $\begin{array}{l}\text { Agoraphobia-Mobility } \\
\text { Inventory (17) }\end{array}$ & Agoraphobia & $\begin{array}{l}\text { Qualitative (places } \\
\text { avoided) }\end{array}$ \\
\hline
\end{tabular}




\begin{tabular}{|c|c|c|}
\hline $\begin{array}{l}\text { Obsessive- } \\
\text { Compulsive Inventory } \\
(\mathrm{OCl})(18)\end{array}$ & OCD & 42 items \\
\hline $\begin{array}{l}\text { Panic Disorder } \\
\text { Severity Scale (PDSS) } \\
(19)\end{array}$ & Panic disorder & 7 items \\
\hline $\begin{array}{l}\text { Patient Health } \\
\text { Questionnaire } \\
\text { (Physical symptoms) } \\
(\text { PHQ-15) (20) }\end{array}$ & $\begin{array}{l}\text { Physical } \\
\text { symptoms } \\
\text { (somatic } \\
\text { symptoms) }\end{array}$ & 15 items \\
\hline $\begin{array}{l}\text { Francis Irritable Bowel } \\
\text { Scale (21) }\end{array}$ & IBS & 5 items \\
\hline $\begin{array}{l}\text { The Chalder Fatigue } \\
\text { Scale (22) }\end{array}$ & $\begin{array}{l}\text { Chronic Fatigue } \\
\text { Syndrome }\end{array}$ & 11 items \\
\hline $\begin{array}{ll}\text { Work \& } & \text { Social } \\
\text { Adjustment } & \text { Scale } \\
(\text { WASA) (23) } & \end{array}$ & $\begin{array}{l}\text { Impairment in daily } \\
\text { functioning }\end{array}$ & 5 items \\
\hline
\end{tabular}


Table 2. Psychological co-morbidities and functional disorders reported in women with chronic idiopathic urinary retention

\begin{tabular}{|c|c|}
\hline Study, number of patients & Co-morbidities reported \\
\hline $\begin{array}{l}\text { de Ridder et al. } 2007 \text { (4) } \\
n=62\end{array}$ & $\begin{array}{l}\text { Somatization } n=22 \\
\text { Depression } n=15\end{array}$ \\
\hline $\begin{array}{l}\text { Everaert et al. } 2000(6) \\
n=38\end{array}$ & $\begin{array}{l}\text { "hysteria" n=22 } \\
\text { Depression n=6 }\end{array}$ \\
\hline $\begin{array}{l}\text { Hoeritzauer et al. } 2016(10) \\
n=62\end{array}$ & $\begin{array}{l}\text { Psychological disorders } \\
\text { Anxiety/depression } n=18 \\
\text { Obsessive compulsive } \\
\text { symptoms } n=3 \\
\text { Functional Disorders } \\
\text {-Functional } \quad \text { neurological } \\
\text { symptoms: loss } \\
\text { consciousness } \quad(n=7), \quad \text { limb } \\
\text { weakness } \quad(n=6), \quad \text { sensory } \\
\text { disturbances } \quad(n=6), \quad \text { memory } \\
\text { impairment }(n=3) \quad\end{array}$ \\
\hline
\end{tabular}




\begin{tabular}{|l|l|}
\hline & $\begin{array}{l}\text {-Unexplained chronic pain } \\
\text { syndromes }(n=31)\end{array}$ \\
\hline
\end{tabular}


Table 3. "Urinary Retention” appearing in the Diagnostic and Statistical Manual (DSM)

\begin{tabular}{|c|c|c|}
\hline & Somatization disorders & Conversion Disorders \\
\hline $\begin{array}{l}\text { DSM-III-R } \\
(61)\end{array}$ & $\begin{array}{l}\text { Symptom Groups include } \\
\text { group of 'Conversion or } \\
\text { pseudoneurologic } \\
\text { symptoms'. } \\
\text { UR is specifically } \\
\text { mentioned as an example } \\
\text { of 'conversion or } \\
\text { pseudoneurologic } \\
\text { symptoms' }\end{array}$ & $\begin{array}{l}\text { (or hysterical neurosis, } \\
\text { conversion type). } \\
\text { UR not specifically } \\
\text { mentioned. }\end{array}$ \\
\hline $\begin{array}{l}\text { DSM-IV-TR } \\
(62)\end{array}$ & $\begin{array}{l}\text { UR is specifically } \\
\text { mentioned as an example } \\
\text { of a 'pseudoneurological } \\
\text { symptom'. }\end{array}$ & $\begin{array}{l}\text { UR is specifically } \\
\text { mentioned as an } \\
\text { example of a symptom of } \\
\text { conversion disorder }\end{array}$ \\
\hline
\end{tabular}

UR: urinary retention 
Table 4. Historical cases of urinary retention treated with therapies targeting presumed psychological mechanisms

\begin{tabular}{|c|c|c|}
\hline Reference & Summary & Treatment/ outcome \\
\hline $\begin{array}{l}\text { Williams and } \\
\text { Johnson (52) }\end{array}$ & $\begin{array}{l}\text { Case report } \\
\text { (female); } \\
\text { caused } \\
\text { 'emotional conflicts' } \\
\text { after emotional and } \\
\text { sexual abuse }\end{array}$ & $\begin{array}{l}\text { Psychotherapy- } \\
\text { enabled expression } \\
\text { of anger } \\
\text { Outcome: successful }\end{array}$ \\
\hline Chapman (64) & $\begin{array}{l}\text { Case study } \\
\text { (female); childhood } \\
\text { trauma. Patient } \\
\text { unassertive and } \\
\text { exploited by family }\end{array}$ & $\begin{array}{l}\text { Psychotherapy- } \\
\text { subsequent } \\
\text { enhanced } \\
\text { confidence and } \\
\text { assertiveness } \\
\text { Outcome: successful }\end{array}$ \\
\hline Larson et al.(65) & $\begin{array}{l}\text { Case study in series } \\
\text { of } 37 \text { women with } \\
\text { UR and other } \\
\text { symptoms. } \\
\text { Diagnosis: schizo- } \\
\text { affective disorder. }\end{array}$ & $\begin{array}{l}\text { Psychotherapy- } \\
\text { enabled expression } \\
\text { of hatred and rage } \\
\text { towards therapist or } \\
\text { other male }\end{array}$ \\
\hline
\end{tabular}




\begin{tabular}{|c|c|c|}
\hline & & $\begin{array}{l}\text { physicians } \\
\text { Outcome: } \\
\text { successful. UR } \\
\text { improved although } \\
\text { some other } \\
\text { symptoms remained }\end{array}$ \\
\hline $\begin{array}{l}\text { Wahl and Golden } \\
\text { (66) }\end{array}$ & $\begin{array}{l}\text { UR (5 female, } 1 \\
\text { male); } \quad \text { Multiple } \\
\text { "repressed, genital } \\
\text { sexual conflicts" }\end{array}$ & $\begin{array}{l}\text { Psychotherapy and } \\
\text { psychoeducation } \\
\text { Outcome: successful }\end{array}$ \\
\hline Cooper (67) & $\begin{array}{l}\text { Case report } \\
\text { (female) }\end{array}$ & $\begin{array}{l}\text { Reassurance, } \\
\text { psychoeducation and } \\
\text { carbachol injection } \\
\text { followed by injections } \\
\text { of sterile water } \\
\text { Outcome: successful. } \\
\text { UR improved at } 4 \\
\text { months follow-up }\end{array}$ \\
\hline Barnard et al. (68) & $\begin{array}{l}\text { Case } \\
\text { (female) }\end{array}$ & $\begin{array}{l}\text { Treatment: electrical } \\
\text { stimulus to legs and } \\
\text { programme of verbal }\end{array}$ \\
\hline
\end{tabular}




\begin{tabular}{|c|c|c|}
\hline & & $\begin{array}{l}\text { and non-verbal } \\
\text { reinforcement' } \\
\text { suggestive } \\
\text { assertiveness } \\
\text { training } \\
\text { Outcome: } \\
\text { successful. } \quad \text { UR } \\
\text { cured; } \\
\text { dependent and } \\
\text { anxious; } \quad \text { more } \\
\text { assertive }\end{array}$ \\
\hline Barrett (69) & $\begin{array}{l}\text { 9/12 patients with } \\
\text { UR sent for } \\
\text { psychiatric } \\
\text { evaluation }\end{array}$ & $\begin{array}{l}\text { Bladder training, } \\
\text { intermittent self- } \\
\text { catheterisation and, } \\
\text { when indicated, } \\
\text { additional 'psychiatric } \\
\text { support'. } \\
\text { Outcome: } \\
\text { patients voiding } \\
\text { normally at discharge }\end{array}$ \\
\hline
\end{tabular}




\begin{tabular}{|c|c|c|}
\hline $\begin{array}{l}\text { Montague and } \\
\text { Jones (70) }\end{array}$ & 6 patients & $\begin{array}{l}\text { Management and } \\
\text { treatment included } \\
\text { biofeedback, } \\
\text { behaviour therapy, } \\
\text { individual } \\
\text { psychotherapy, group } \\
\text { therapy, couples } \\
\text { therapy, biofeedback- } \\
\text { monitored relaxation } \\
\text { training, introduction } \\
\text { of 'imagery' during } \\
\text { periods of deep } \\
\text { relaxation. } \\
\text { Outcome: successful }\end{array}$ \\
\hline Bird (71) & 2 cases (females) & $\begin{array}{l}\text { Analytical } \\
\text { psychotherapy } \\
\text {-enabled to express } \\
\text { 'unacceptable } \\
\text { aggressive rage' } \\
\text { Outcome: successful }\end{array}$ \\
\hline
\end{tabular}




\begin{tabular}{|l|ll|lr|}
\hline Wheeler et al. (72) & $\begin{array}{l}\text { 12 women with UR } \\
\text { with psychological }\end{array}$ & psychotherapy & not \\
& history & reported. & \\
& & Outcomes: & not \\
& & reported & \\
\hline
\end{tabular}

UR: urinary retention 